EPJ Web of Conferences 12, 01001 (2011)

DOI: $10.1051 /$ epjconf/20111201001

(C) Owned by the authors, published by EDP Sciences, 2011

\title{
Overview of activities in the U.S. related to continued service of nuclear power plant concrete structures
}

\author{
D.J. Naus ${ }^{a}$ \\ Oak Ridge National Laboratory, Oak Ridge, Tennessee 37831-6069, USA
}

\begin{abstract}
Safety-related nuclear power plant concrete structures are described and commentary on continued service assessments of these structures is provided. In-service inspection and testing requirements in the U.S. are summarized. The license renewal process in the U.S. is outlined and its current status noted. A summary of operating experience related to U.S. nuclear power plant concrete structures is presented. Several candidate areas are identified where additional research would be of benefit to aging management of NPP concrete structures. Finally current ORNL activities related to aging-management of concrete structures are outlined: development of operating experience database, application of structural reliability theory, and compilation of elevated temperature concrete material property data and information.
\end{abstract}

\section{INTRODUCTION}

In the United States, the Atomic Energy Act and regulations of the United States Nuclear Regulatory Commission (USNRC) limit commercial power reactor licenses to an initial 40-year period, ${ }^{*}$ but also permits such licenses to be renewed. This original 40-year term for reactor licenses was based on economic and antitrust considerations - not on limitations of nuclear technology. Due to this selected period, however, some structures and components may have been engineered on the basis of an expected 40-year service life. In order to ensure the safe operation of nuclear power plants (NPPs), it is essential that the effects of age-related degradation of plant structures, as well as systems and components, be assessed and managed during both the current operating license period as well as subsequent license renewal periods.

\section{CONCRETE STRUCTURES}

All commercial NPPs in the U.S. contain concrete structures whose performance and function are necessary for protection of the safety of plant operating personnel and the general public, as well as the environment. A myriad of concrete-based structures are contained as a part of a light-water reactor (LWR) plant to provide foundation, support, shielding, and containment functions. Typical safety-related concrete structures contained in LWR plants may be grouped into four general categories: primary containments, containment internal structures, secondary containments/reactor buildings, and other structures.

Of the pressurized-water reactor (PWR) plants that have been licensed for commercial operation in the U.S., approximately $80 \%$ use either reinforced or post-tensioned concrete primary containments. The concrete containments are of three different functional designs: subatmospheric (reinforced

\footnotetext{
a e-mail: nausdj@ornl.gov

*Other countries may not have a limit set on the plant operating license period but the utility must obtain a permanent renewal of its operating license subject to numerous and continuous justifications (e.g., periodic safety reevaluations).

This is an Open Access article distributed under the terms of the Creative Commons Attribution-Noncommercial License 3.0, which permits unrestricted use, distribution, and reproduction in any noncommercial medium, provided the original work is properly cited.
} 
concrete), ice condenser (reinforced concrete), and large/dry (reinforced and prestressed concrete). The primary differences between these containment designs relate to volume requirements, provisions for accident loadings/pressures, and containment internal structures layout. The PWR containment structure generally consists of a concrete basemat foundation, vertical cylindrical walls, and dome. Leak tightness of a containment is provided by a steel liner attached to the containment inside surfaces. Exposed surfaces of the carbon steel liner are typically painted to protect against corrosion and to facilitate decontamination should it be required. Depending on the functional design (e.g., large dry or ice condenser), the concrete containments can be on the order of 40 to $50 \mathrm{~m}$ in diameter and 60 to $70 \mathrm{~m}$ high, with wall and dome thicknesses from 0.9 to $1.4 \mathrm{~m}$, and base slab thicknesses from 2.7 to $4.1 \mathrm{~m}$. In PWR plants that utilize a metallic primary containment (large dry and ice condenser designs), the metallic containment is usually contained in a reinforced concrete "enclosure" or "shield" building that, in addition to withstanding environmental effects, provides radiation shielding and particulate collection, and ensures that the free-standing metallic primary containment is protected from the natural environment.

Of the boiling-water reactor (BWR) plants in the U.S., approximately $30 \%$ utilize either reinforced or prestressed concrete primary containments. BWR containments, because of provisions for pressure suppression, typically have "normally dry" sections (dry well) and "flooded" sections (wet well) that are interconnected via piping or vents. BWR plants that utilize steel primary containments have reinforced concrete structures that serve as secondary containments or reactor buildings. These structures generally are safety-related because they provide additional radiation shielding; provide resistance to environmental and operational loadings; and house safety-related mechanical equipment, spent fuel, and the primary metal containment. Although these structures may be massive in crosssection in order to meet shielding or load-bearing requirements, they generally have smaller elemental thicknesses than primary containments because of reduced exposure under postulated accident loadings.

\section{CONTINUED SERVICE ASSESSMENTS}

Guidelines for production of durable concrete are available in national consensus codes and standards that have been developed over the years through knowledge acquired in testing laboratories and supplemented by field experience (e.g., ACI 318 [1]). Serviceability of concrete has been incorporated into the codes through strength requirements and limitations on service load conditions in the structure (e.g., allowable crack widths, limitations on mid-span deflections of beams, and maximum service level stresses in prestressed members). Durability has been included in the design through specifications for maximum water-cement ratios, requirements for entrained air, minimum concrete cover over reinforcement, etc. Service-related degradation, however, can affect the performance of NPP concrete structures. As these plants mature, environmental factors are going to become increasingly important. Demonstration of continued safe and reliable operation of the plants will involve implementation of a program that effectively manages aging to ensure the availability of design safety functions throughout the plant service life. General guidance on developing an aging management program for concrete containment buildings has been developed [2]. Additional information is available through organizations such as The Electric Power Research Institute; The International Union of Laboratories and Experts in Construction Materials, Systems and Structures; and the Nuclear Energy Agency Committee on the Safety of Nuclear Installations under its Integrity of Components and Structures Working Group.

Operating experience has demonstrated that periodic inspection, maintenance, and repair are essential elements of an overall program to maintain an acceptable level of reliability over the service life of a NPP containment, or in fact, of any structural system. Knowledge gained from conduct of an in-service condition assessment can serve as a baseline for evaluating the safety significance of any degradation that may be present, and defining subsequent in-service inspection programs, and maintenance strategies. Effective in-service condition assessment of a structure requires knowledge of the expected type of degradation, where it can be expected to occur, and application 
AMP 2010

of appropriate methods for detecting and characterizing the degradation. Degradation is considered to be any phenomenon that decreases a structure's load-carrying capacity, limits its ability to contain a fluid medium, or reduces its service life. Degradation detection is the first and most important step in the condition assessment process. Routine observation, general visual inspections, leakage-rate tests, and nondestructive examinations are approaches used to identify areas of a structure that have experienced degradation. Techniques for establishing time-dependent change such as section thinning due to corrosion, or changes in component geometry and material properties, involve monitoring or periodic examination and testing. Knowing where to inspect and what type of degradation to anticipate often requires information about the design features of the NPP structures as well as the materials of construction and environmental factors. A number of documents are available to assist in development and conduct of structural condition assessment programs and providing guidance addressing assessment of concrete degradation [3-22].

\section{IN-SERVICE INSPECTION AND TESTING REQUIREMENTS}

In-service inspection programs for NPP structures have the primary goal of ensuring that the structures have sufficient structural margins to continue to perform in a reliable and safe manner [23, 24]. A secondary goal is to identify environmental stressors or aging factor effects before they reach sufficient intensity to potentially degrade structural components.

One of the conditions of all operating licenses for water-cooled power reactors in the U.S. is that the primary reactor containments shall meet the containment leakage test requirements set forth in Appendix J, "Primary Reactor Containment Leakage Testing for Water-Cooled Power Reactors," to 10 CFR 50 [25]. These test requirements provide for preoperational and periodic verification by tests of the leak-tight integrity of the primary reactor containment, and systems and components that penetrate containment of water-cooled power reactors, and establish the acceptance criteria for such tests. The purpose of these tests is to assure that: (1) leakage through the primary reactor containment and the systems and components penetrating primary reactor containment shall not exceed allowable leakagerate values as specified in the technical specifications or associated bases, and (2) periodic surveillance of reactor containment penetrations and isolation valves is performed so that proper maintenance and repairs are made during the service life of the containment, and systems and components that penetrate primary containment. Contained in this regulation are requirements pertaining to Type $\mathrm{A}, \mathrm{B}$, and $\mathrm{C}$ leakage-rate tests that must be performed by each licensee as a condition of their operating license. Type A tests are intended to measure the primary reactor containment overall integrated leakage rate (1) after the containment has been completed and is ready for operation, and (2) at periodic intervals thereafter. Type B tests are intended to detect local leaks and to measure leakage across each pressurecontaining or leakage-limiting boundary for primary reactor containment penetrations (e.g., penetrations that incorporate resilient seals, gaskets, or sealant compounds; and air lock door seals). Type C tests are intended to measure containment isolation valve leakage rates. Requirements for system pressure testing and criteria for establishing inspection programs and pressure-test schedules are contained in Appendix $\mathrm{J}$ to 10 CFR 50 [23].

Appendix J to 10 CFR Part 50, also requires a general visual inspection of the accessible interior and exterior surfaces of the containment structures and components to uncover any evidence of structural deterioration that may affect either the containment structural integrity or leak-tightness. Subsection IWL of ASME Code Section XI [20] addresses reinforced and post-tensioned concrete containments (Class CC). Two examination categories are provided in Subsection IWL. Examination Category LA addresses accessible concrete surfaces and examines them for evidence of damage or degradation, such as cracks. The concrete is examined at 1,3, and 5 years following the containment structural integrity test and every 5 years thereafter. The primary inspection method of Category L-A is visual examination (general or detailed). Examination Category L-B addresses the unbonded post-tensioning system. The unbonded post-tensioning system examination schedule is the same as for the concrete. For 
post-tensioned concrete containments, a sample of tendon wires is tested for yield strength, ultimate tensile strength, and elongation. Tendon corrosion protection medium is analyzed for alkalinity, water content, and soluble ion concentrations. Prestressing forces are measured for selected sample tendons. Subsection IWL specifies acceptance criteria, corrective actions, and expansion of the inspection scope when degradation exceeding the acceptance criteria is found. Additional requirements for inaccessible areas are specified in 10 CFR 50.55a(b)(2)(viii). The acceptability of concrete in inaccessible areas is to be evaluated when conditions exist in accessible areas that could indicate the presence or result in degradation to such inaccessible areas. Guidelines for the evaluation of existing nuclear safetyrelated concrete structures (other than containments), including acceptance criteria have been developed by organizations such as the American Concrete Institute [10]. Information on aging management programs for NPP masonry walls [26, 27] and water-control structures [28] also is available. Inspection requirements for steel containments and liners of concrete containments are contained in Subsection IWE of ASME Code Section XI [20]. Acceptable editions and addenda of the ASME Code are identified in 10 CFR 50.55a.

\section{LICENSE RENEWAL}

As of August 2009 there were 104 commercial nuclear power reactors licensed to operate in 31 states in the United States. These reactors were provided by 4 different reactor vendors, involve 26 operating companies, have 80 different designs, and are located at 65 sites [29]. The first of the 40-year initial operating licenses in the U.S. was scheduled to expire in 2009 , with about $10 \%$ of the licenses expiring by the end of 2010 and $40 \%$ by the end of 2015. In order to help assure an adequate energy supply, the USNRC has established a timely license renewal process and clear requirements that are needed to ensure safe plant operation for an extended plant life. These requirements are codified in Parts 54 (License Renewal Rule) and 51 (Environmental Regulations) of Title 10, "Energy," of the Code of Federal Regulations and provides for a renewal of an operating license for an additional 20 years. The two basic principals of license renewal are that the regulatory process is adequate to ensure the safety of all currently operating plants, with the possible exception of the detrimental effects of aging, and the plant-specific operating basis must be maintained during the renewal term in the same manner and to the same extent as during the original licensing term.

If a reactor operator seeks to extend its original license it must submit an application to the US Nuclear Regulatory Commission for an independent evaluation of the safety and environmental issues related to license renewal. A NPP licensee may apply to the USNRC to renew its license as early as 20 years before expiration of its current license. The license renewal application: identifies any reactor system, structure, or component that would be affected by license renewal; demonstrates that it can manage the adverse effects of aging during the renewal period; and analyzes the environmental effects of extended reactor operation. Information contained in the license renewal application and the applicant's implementation of license renewal activities is verified by USNRC inspections (e.g., regional inspections, scoping/screening inspections, aging management program inspections, and site inspections). The license renewal process is expected to take about 30 months, or 22 months without an adjudicatory hearing.

The focus of the license renewal review is on passive, long-lived structures and components, time-limited aging analyses, and on managing the effects of aging during the period of extended operation. With respect to the concrete-related materials, the structures and components subject to an aging management review can include the containment, containment liner, component supports, and seismic Category I structures. License renewal guidance is provided in documents such as the Generic Aging Lessons Learned (GALL) Report [30] and the Standard Review Plan for License Renewal [31]. Figure 1 summarizes the license renewal process.

The Generic Aging Lessons Learned (GALL) Report [30] has been developed by the USNRC to provide a technical basis for the Standard Review Plan for License Renewal [31]. The GALL 


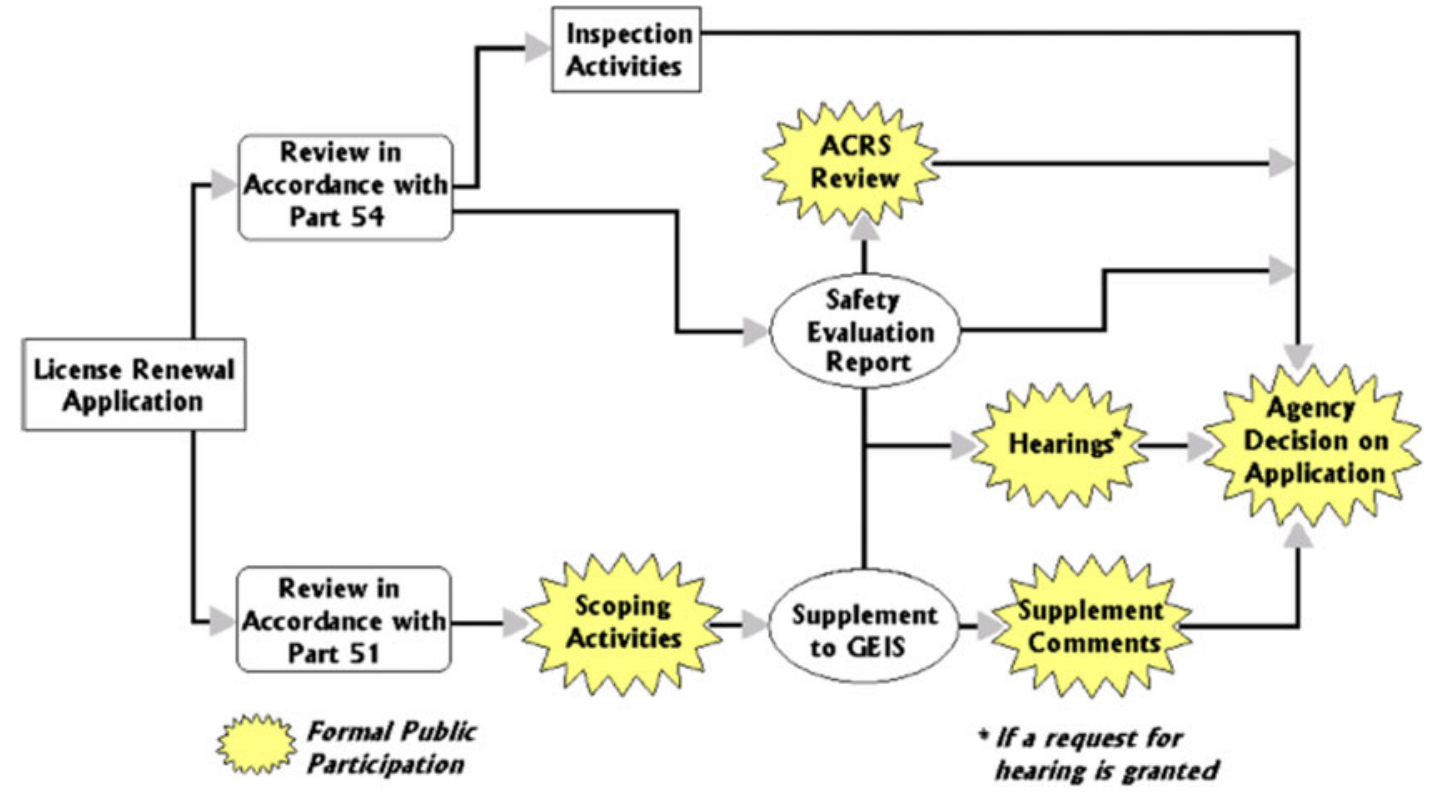

Figure 1. License renewal process. Source: http://www.nrc.gov/reactors/operating/licensing/ renewal/introduction/orientation.html).

Report contains the USNRC Staff's generic evaluation of the existing plant programs and documents the technical bases for determining where existing programs are adequate without modification and where existing programs should be augmented for the extended period of operation. The GALL Report incorporates guidance from professional organizations such as the American Concrete Institute and American Society of Civil Engineers [1, 10, 19, 32-34], can be used to evaluate existing aging management programs, and documents the technical basis for determining where existing programs are adequate without modification and where existing programs should be augmented. Sections of the report address containment structures, other Class 1 structures, and component supports. Each structure and/or component is identified as well as its material(s) of construction, environment, aging effects/mechanisms, acceptable programs to manage the effects of aging, and if further evaluation is required.

The Standard Review Plan [31] has the purpose of assuring the quality and uniformity of USNRC Staff reviews and to present a well-defined base from which to evaluate a licensee's application. This report incorporates by reference the GALL Report and Regulatory Guide 1.188. Regulatory Guide 1.188 [35] provides the format and content for applications and endorses NEI 95-10, Rev. 6 [36], however, applicants may elect to use other suitable methods or approaches for satisfying the License Renewal Rule's requirements and completing a license renewal application. NEI 95-10, Rev. 6, provides guidance to applicants in preparing their license renewal applications. Major elements of this document address: identification of systems, structures, and components within the scope of license renewal; identification of the intended functions of systems, structures, and components within the scope of license renewal; identification of the structures and components subject to aging management review and intended functions; assurance that the effects of aging are managed; application of new programs and inspections for license renewal; identification and resolution of time-limited aging analyses; identification and evaluation of exemptions containing time-limited aging analyses; and identification of a standard format and content of a license renewal application. 
Additional sources of guidance related to license renewal include: inspection manual chapters and procedures, license renewal interim staff guidance, office instructions, regulatory guides, technical reports in NUREG series, and nuclear plant aging research reports. As of July 2010, 59 units have completed license renewal applications, 20 units are currently under review, and 17 units have indicated that they plan future submitals .

\section{OPERATING EXPERIENCE}

Overall, the performance of NPP safety-related concrete structures has been very good. Initially, degradation of NPP concrete structures in the U.S. occurred early in their life and has been corrected [37-39]. Causes were primarily related either to improper material selection and construction/design deficiencies, or environmental effects. Examples of some of the problems attributed to these deficiencies include low 28-day concrete compressive strengths, voids under the post-tensioning tendon bearing plates resulting from improper concrete placement; cracking of post-tensioning tendon anchor heads due to stress corrosion or embrittlement; and containment dome delaminations due to low quality aggregate materials and absence of radial steel reinforcement or unbalanced prestressing forces [40-42]. Other construction-related problems included occurrence of excessive voids or honeycomb in the concrete, contaminated concrete, cold joints, cadweld (steel reinforcement connector) deficiencies, materials out of specification, higher than code allowable concrete temperatures, misplaced steel reinforcement, post-tensioning system button-head deficiencies, and water-contaminated corrosion inhibitors [37].

Although continuing the service of a NPP past the initial operating license period is not expected to be limited by the concrete structures, several incidences of age-related degradation have been reported [39-44]. Examples of some of these problems include corrosion of steel reinforcement in water intake structures, corrosion of post-tensioning tendon wires, leaching of tendon gallery concrete, low prestressing forces, and leakage of corrosion inhibitors from tendon sheaths. Other related problems include cracking and spalling of containment dome concrete due to freeze-thaw damage, low strengths of tendon wires, contamination of corrosion inhibitors by chlorides, and corrosion of concrete containment liners. As the plants age the incidences of degradation are expected to increase, primarily due to environmental effects. A listing of documented concrete problem areas by plant, type reactor, and degradation is available [8]. Documented information on problem areas experienced with NPP concrete structures in other countries has also been assembled [2]. Figure 2 presents examples of occurrences of degradation that have been observed at NPPs. Anchor head failure and the containment dome delamination repair shown in the figure represent occurrences related to materials selection and design, respectively, and were not aging related. The remainder of the examples represent aging-related occurrences.

\section{UPDATE ON CURRENT AGING MANAGEMENT-RELATED ACTIVITIES AT ORNL}

In February 2008, the U.S. Department of Energy (USDOE) and USNRC sponsored a three-day workshop on U.S. NPP life extension research and development in order to gain a better understanding from stakeholders and the scientific community on needed research to support continued operation of current light-water reactors (LWRs) beyond a 60-year lifetime [45]. The specific goals of this workshop were to: (1) identify research topics that address technology barriers and challenges that may produce disruptive conditions to long term operations of LWRs; (2) identify a set of prioritized research pathways; (3) identify cross-cutting research topics that may impact long-term operation; (4) identify significant research challenges that would significantly improve long-term LWR operations; and (5) identify appropriate roles and responsibilities for industry, USDOE, and USNRC in a collaborative research agenda that will ensure safe, long-term LWR operation. The proceedings of this workshop are available [46]. 


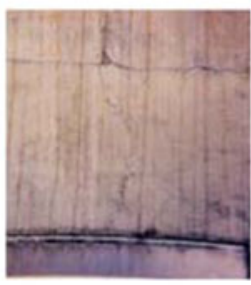

Concrete Cracking Outside Containment Wall

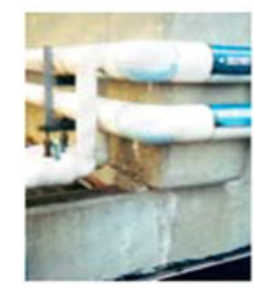

Exterior Concrete Wall Cracks and Spalling

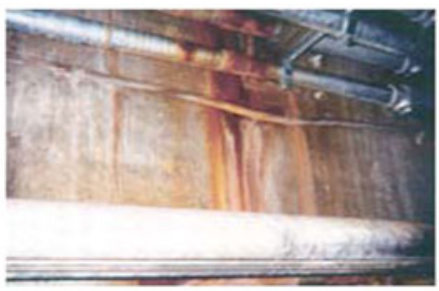

Concrete Wall Water Infiltration

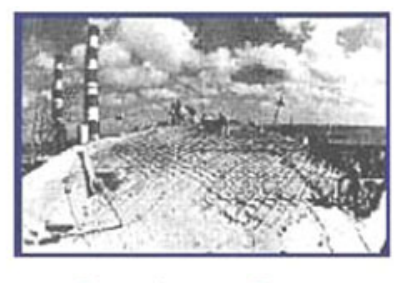

Containment Dome Delamination Repair

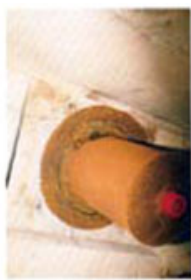

Corrosion of Grease Cap

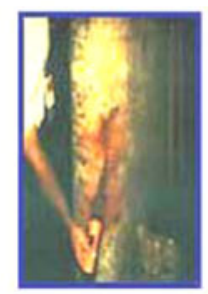

Water Intake Structure Rebar Corrosion Outside Containment Wall

Figure 2. Examples of degradation related to NPP concrete structures.

Two of the presentations at the workshop [47, 48] addressed research needs related to concrete materials and structures. Structural research topics identified in these presentations included: (1) compilation of material property data for long-term performance and trending, evaluation of environmental effects, and assessment and validation of nondestructive evaluation methods; (2) evaluation of long-term effects of elevated temperature and radiation; (3) improved damage models and acceptance criteria for use in assessments of the current as well as estimating the future condition of the structures: (4) improved constitutive models and analytical methods for use in determining nonlinear structural response (e.g., accident conditions); (5) non-intrusive methods for inspection of thick, heavily-reinforced concrete structures and basemats; (6) global inspection methods for metallic pressure boundary components (i.e., liners of concrete containments and steel containments) including inaccessible areas and backside of liner; (7) data on application and performance (e.g., durability) of repair materials and techniques; (8) utilization of structural reliability theory incorporating uncertainties to address time-dependent changes to structures to assure minimum accepted performance requirements are exceeded and to estimate on-going component degradation to estimate end-of-life; and (9) application of probabilistic modeling of component performance to provide risk-based criteria to evaluate how aging affects structural capacity. Two of these areas are currently being addressed under the DOE Light-Water Reactor Sustainability Program [49] that is a research and development program, performed in close collaboration with industry research and development programs, to provide the technical foundations for licensing and managing the long-term, safe, and economical operation of current NPPs - development of an operating experience database and application of structural reliability theory.

\section{OPERATING EXPERIENCE DATABASE}

Nuclear safety-related concrete structures are composed of several constituents that, in concert, perform multiple functions (e.g., load-carrying capacity, radiation shielding, and leak tightness). Primarily, these constituents include the following material systems: concrete, conventional steel reinforcement, prestressing steel, steel liner plate, and embedment steel. Data on the long-term performance of 


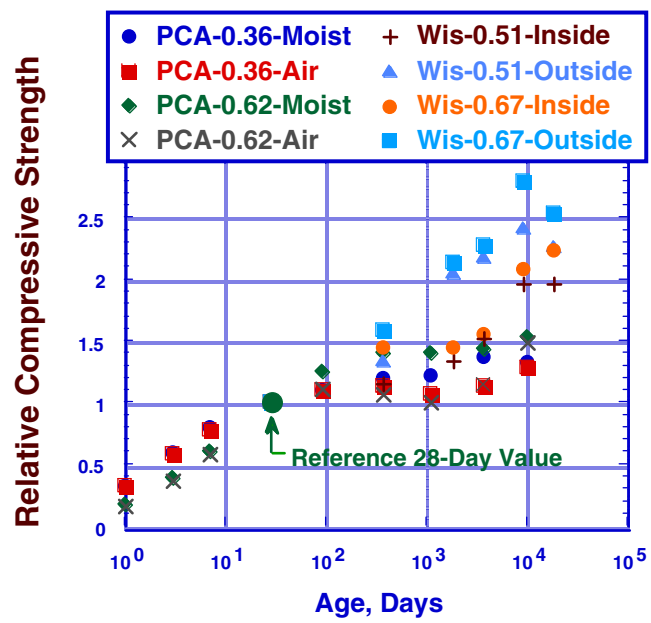

Long-Term Laboratory Data

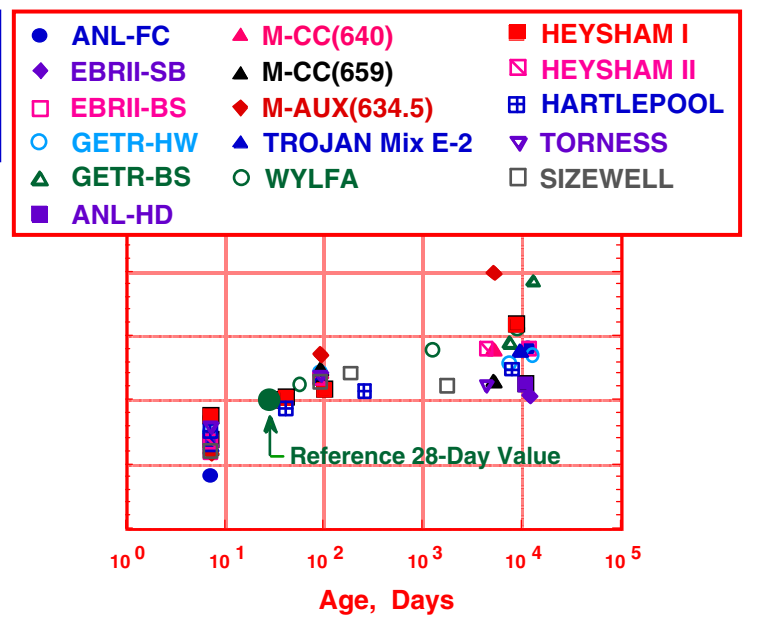

Nuclear Power Plant Data

Figure 3. Normalized concrete compressive strength data obtained from the literature and by testing nuclear power plant-related concrete samples.

the reinforced concrete materials is of importance for demonstrating the durability of the NPP concrete structures, and in predicting their performance under the influence of pertinent aging factors and environmental stressors. This information also has application to establishing limits on hostile environmental exposure for these structures and to development of inspection and maintenance programs that will prolong component service life and improve the probability of the component surviving an extreme event such as a loss-of-coolant accident.

Reviews of research conducted on concrete materials and structures indicate that only limited data are available on the long-term (40 to 80 years) properties of reinforced concrete materials [37]. Where concrete properties have been reported for conditions that have been well-documented, the results were generally for concretes having ages $<5$ years, or for specimens that had been subjected to extreme, nonrepresentative environmental conditions such as seawater exposure or accelerated aging. Relatively few investigations were reported providing results on examinations of structures that had been in service for the time period of interest, 20 to 100 years, and they did not generally provide the "high quality" baseline information (e.g., baseline material characteristics and changes in material properties with time) that is desired for meaningful assessments to indicate how the structures have changed under the influence of aging factors and environmental stressors.

Limited data on the long-term performance of reinforced concrete materials reported in the literature, results from concrete cores removed from NPPs, and specimens cast in conjunction with NPP facilities have been reported [50]. As noted in Figure 3, these results generally show an increase in compressive strength (relative to 28 -d reference strength) at a decreasing rate with age, but the data obtained from the literature were for concrete ages $<50$ years and the nuclear plant data for ages $<27$ years.

With the availability of decommissioned NPPs and plant modifications requiring removal of materials, opportunities exist to obtain samples for use in providing an improved understanding of the effects of extended exposure under the conditions found in NPPs. Removal and testing of the material samples from decommissioned plants has application in demonstrating that under normal conditions the properties of structural materials are not adversely affected by aging, and providing guidance for estimating the magnitude of change in material properties with time. Obtaining actual changes in concrete property data with time provides information that can be utilized to estimate in-situ concrete strengths where conditions prevent the removal and testing of materials, and in predicting what 
AMP 2010

the effects of an environmental stressor (e.g., elevated temperature) would be on concrete strength. In regions where degradation has occurred, the results can be used to quantify the significance of degradation as well as it's potential impact on structural performance during low-probability events (i.e., assist in establishing criteria for use during structural condition assessments). Since selection of areas for removal of samples will require conduct of a condition assessment to baseline the condition of the structures and identify areas experiencing degradation as well as those at greatest risk (e.g., buried structures, regions of elevated temperature, and areas where fluids can accumulate), information will be provided on the effectiveness of the plant programs for managing the effects of aging. Removal and testing of concrete samples from buried foundations and basemats, particularly in areas subject to fluctuating groundwater levels or soils having high sulfate or chloride contents, provides an opportunity to evaluate the effectiveness of the current practice of monitoring adjacent accessible regions of the structure, or monitoring the adjacent soil or groundwater. Potential additional applications of the concrete material sampling activity would be to: indicate the overall quality of construction and as-built conditions, provide improved characterization of environments for development of improved damage models and acceptance criteria, assess and validate non-destructive testing methods, evaluate repair activities, and provide information for application to new plant designs. Results obtained from activities such as described can be input into an operational database to help monitor and benchmark specific plant performance.

In parallel with compilation of the material property data on long-term aging and environmental effects, a web-based Nuclear Concrete Materials Database (NCMD) is being developed with the capability of global access. The NCMD will contain and manage both historical and newly-generated data and information for concrete and concrete-related materials used in the design and construction of nuclear energy systems. The advanced materials property information management system developed for the Gen IV Nuclear Energy Systems Program, the Gen IV Materials Handbook System [51], is being used to develop the NCMD to take advantage of the information management infrastructure already in place.

Development of the NCMD is divided into two phases. In Phase I, a document database has been designed and constructed to store and manage historical data and information on concrete materials. The major focus of Phase I development was to keep the characteristics of original historical data and information documents that are familiar to scientists and engineers who have been working with such documents. Historical data and information are being uploaded as Portable Document Format (PDF) and/or Microsoft Word files into a well-organized database structure with certain rudimentary search abilities. Users can conduct search operations to find the documents they need and conveniently print out or review the data and information on their computer screens. In Phase II, a digitized database will be designed and constructed to store and manage the historical and newly generated data and information. The major focus of Phase II development will be to enable advanced data processing functionalities. Data and information will be stored and managed in digitized form in the database structure with powerful searching, reporting, tabulating, plotting, comparing, and many other desirable data processing and information management capabilities. The digitized database will not only store data and information, but also register the relationships between data and information to enable accurate traceability to satisfy pedigree and prediction research needs. Since both the previously developed SMIC and the NCMD currently being developed use the same formatting structure as the Nuclear Systems Materials Handbook that was developed in the 1970's under the Liquid-Metal Fast-Breeder Reactor Program [52], initial data and information input into the NCMD will be provided by the Structural Materials Information Center that was developed under the USNRC Structural Aging Program [7].

\section{APPLICATION OF STRUCTURAL RELIABILITY THEORY}

If properly designed and constructed, the concrete structures in NPPs generally have substantial safety margins; however, additional information for quantifying the available margins of degraded 
structures is desired. In addition, how age-related degradation may affect dynamic properties (e.g., stiffness, frequency, and dampening), structural response, structural resistance/capacity, failure mode, and location of failure initiation is not well understood. A better knowledge of the effects of aging degradation on structures and passive components will help ensure that the current licensing basis is maintained under all loading conditions [53].

Service-related degradation of reinforced or prestressed concrete structures, systems and components (SSCs) can occur due to aging that if not addressed may impact their ability to respond to extreme environmental or accidental events at or beyond their design bases. Many of these facilities now have reached a point in their service lives where structural deterioration may have occurred in reinforced concrete or steel structural components and systems [54, 55]. Aggressive physical (e.g., freeze-thaw, thermal expansion) and chemical (e.g., sulfate attack, reactive aggregates) mechanisms can lead to degradation of concrete strength and performance, while the primary mechanisms affecting steel structures is corrosion. Decisions as to whether to invest in maintenance and rehabilitation of structures, systems and components as a condition for continued service and risk mitigation, and the appropriate level of investment, should consider the nature and level of uncertainties in their current condition and in future demands [56-58].

Recent advances in structural reliability analysis, uncertainty quantification, and probabilistic risk assessment make it possible to perform such evaluations and to devise uniform risk-based criteria by which existing facilities can be evaluated to achieve a desired performance level when subjected to uncertain demands [59]. The standard and regulatory community has adopted practical risk-based criteria for new SSCs [60, 61]. Consideration of in situ conditions, redundancy, and uncertainties in important engineering parameters often can lead to significant economic benefits when assessing the condition of an existing structure in a (possibly) degraded condition, and the maintenance or rehabilitation strategies that might be required as a condition for future service. Reliability-based approaches have been applied to the NPP concrete structures $[62,63]$ and in evaluation of the prestress level in concrete containments with unbonded tendons [64]. The state-of-the-art has reached a level where such risk-informed approaches to aging management of reinforced or prestressed concrete SSCs now appear feasible [62, 65-67].

Degradation effects can be quantified with fragility curves developed for both undegraded and degraded components [68]. Fragility analysis is a technique for assessing, in probabilistic terms in the presence of uncertainties, the capability of an engineered system to withstand a specified event. Fragility modeling requires a focus on the behavior of the system as a whole and, specifically, on things that can go wrong with the system. The fragility modeling process leads to a median-centered (or likely) estimate of system performance, coupled with an estimate of the variability or uncertainty in performance. The fragility concept has found widespread usage in the nuclear industry, where it has been used in seismic probabilistic safety and/or margin assessments of safety-related plant systems [69]. The fragility modeling procedures applied to degraded concrete members can be used to assess the effects of degradation on plant risk and can lead to the development of probability-based degradation acceptance limits. This approach has been applied to a limited extent to degraded flexural members and shear walls [53]. Additional work is desired in this area for the purpose of refining and applying the time-dependent reliability methodology for optimizing in-service inspection/maintenance strategies and for developing and evaluating improved quantitative models for predicting future performance (or failure probability) of a degraded concrete structure, either at present or some future point in time.

Under the DOE Light-Water Resctor Sustainability Program a conceptual basis for risk-informed assessment of future safety margins of existing reinforced or prestressed concrete structures, components, and systems in facilities under the purview of the USNRC and DOE is being developed, and the feasibility of such an assessment will be illustrated through a simple test bed problem. This research goal is being accomplished through the following tasks: (1) through a literature review, critically appraise vulnerability of existing SSC to intensities of natural and man-made hazards using recent research findings on structural resistances and loads; (2) identify a set of SSCs to be used as testbeds to 
AMP 2010

demonstrate the risk-informed condition assessment process; (3) identify major sources of aleatoric and epistemic uncertainties in engineering demand and capacity of these SSCs, and develop probabilistic models of these uncertainties to the extent feasible; and (4) develop risk-informed guidelines for evaluation of the critical SSCs identified in Task 1 using structural reliability tools to model the uncertainties identified in Task 3. The final product for this activity will be a report, Guidelines for Risk-Informed Condition Assessment and Evaluation of Aging Concrete Structures, Components, and Systems.

\section{COMPILATION OF ELEVATED TEMPERATURE CONCRETE MATERIAL PROPERTY DATA}

Under normal conditions, most concrete structures are subjected to a range of temperature no more severe than that imposed by ambient environmental conditions. However, there are important cases where these structures may experience much higher temperatures (e.g., jet aircraft engine blasts, building fires, chemical and metallurgical industrial applications in which the concrete is in close proximity to furnaces, and some nuclear power-related postulated accident conditions). Under elevated temperature exposure reinforced concrete structures can fail in a number of different ways [70, 71]. For load-bearing slabs, if the strength of the steel reinforcement is lost due to heating then there may be bending or tensile strength failure. Reinforced members may also fail when the bond between the concrete and reinforcement is lost, with associated concrete tensile failure. Shear or torsion failures are also influenced by concrete tensile strength, but are poorly defined experimentally. Finally, compressive failures are usually associated with temperature-related loss of concrete compressive strength in the compression zone. In practice, failure is related to structural performance in situ (e.g., restraint effects).

The performance of Portland cement-based materials under elevated temperature exposure is very complicated and difficult to characterize. Concrete's thermal properties are more complex than for most materials because not only is the concrete a composite material whose constituents have different properties, but also its properties depend on moisture and porosity. Exposure of concrete to elevated temperature effects its mechanical and physical properties. The changes in properties result from three processes that take place at elevated temperature: (1) phase transformations (e.g., loss of free water at about $100^{\circ} \mathrm{C}$, decomposition of calcium hydroxide at about $450^{\circ} \mathrm{C}$, and crystal transformation of quartz at $573{ }^{\circ} \mathrm{C}$ from the $\alpha$ - to the $\beta$-form), (2) pore structure evolution (e.g., volume and surfaces of pores increase up to a temperature of about $500{ }^{\circ} \mathrm{C}$ and then decrease with further temperature increase, and (3) coupled thermo-hygro-chemo-mechancial processes (e.g., temperature gradients leading to thermal stresses, multiphase transport of water, and chemical changes that affect pore pressure and structure) [72]. Figure 4 provides a summary of the physiochemical processes in Portland cement concrete during heating [70]. Under thermal loading elements could distort and displace and, under certain conditions, the concrete surfaces could spall due to the build up of steam pressure. Because thermally-induced dimensional changes, loss of structural integrity, and release of moisture and gases resulting from the migration of free water could adversely affect plant operations and safety, a complete understanding of the behavior of concrete under long-term elevated-temperature exposure as well as both during and after a thermal excursion resulting from a postulated design-basis accident condition is essential for reliable design evaluations and assessments. Because the properties of concrete change with respect to time and the environment to which it is exposed, an assessment of the effects of concrete aging is also important in performing safety evaluations.

Bonded reinforcement (i.e., deformed bars) is provided to control the extent and width of cracks at operating temperatures, resist tensile stresses and computed compressive stresses for elastic design, and provide structural reinforcement where required by limit condition design procedures. Bonded reinforcement in NPP structures is often used in conjunction with prestressed steel. The prestressed steel provides the structural rigidity and the major part of the strength while the bonded reinforcement distributes cracks, increases ultimate strength, and reinforces those areas not adequately strengthened 


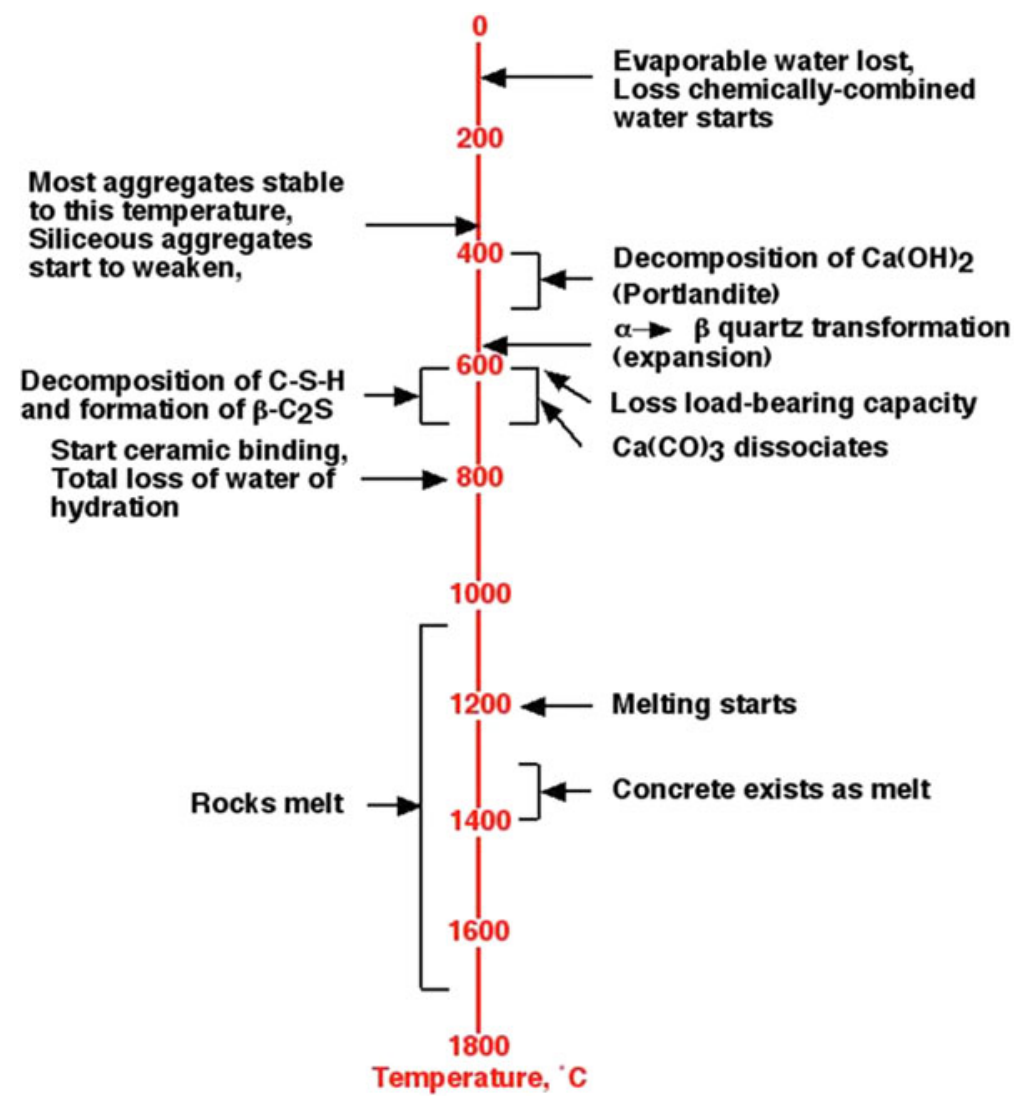

Figure 4. Physiochemical processes in Portland cement concrete during heating. Source: Adaptation of Figure 2 in G.A. Khoury, "Effect of Fire on Concrete and Concrete Structures," Progress in Structural Engineering Materials 2, pp. 429-447, 2000.

by the prestressed steel, and provides additional safety for unexpected conditions of loading. Steel reinforcement is normally protected by the concrete against significant elevated temperature exposure because of concrete's low thermal diffusivity that results in slow propagation of thermal transients. However, under certain conditions such as long-duration thermal exposure, thin-section members, or occurrence of concrete spalling, exposure the reinforcement to elevated temperature can occur. If the temperatures experienced by the steel are high enough, phase transformations can occur that produce changes in its physical and mechanical properties.

The response of concrete to elevated temperature exposure is of interest to the behavior of reinforced concrete elements in designs of new-generation reactor concepts in which the concrete may be exposed to long-term steady-state temperatures in excess of the present American Society of Mechanical Engineers Pressure Vessel and Piping Code (ASME Code) limit of $65^{\circ} \mathrm{C}$ [73] and the performance of concrete associated with radioactive waste storage and disposal facilities and postulated design-basis accident conditions involving unscheduled thermal excursions. Under such applications the affect of elevated temperature on certain mechanical and physical properties of concrete may determine its ability to maintain structural integrity as well as its ability to continue to provide adequate structural margins.

Under USNRC support a report has been prepared providing data and information on the effects of elevated temperature on the properties of concrete materials [74]. This report contains physical and mechanical property data and information on effects of thermal loadings on reinforced concrete 

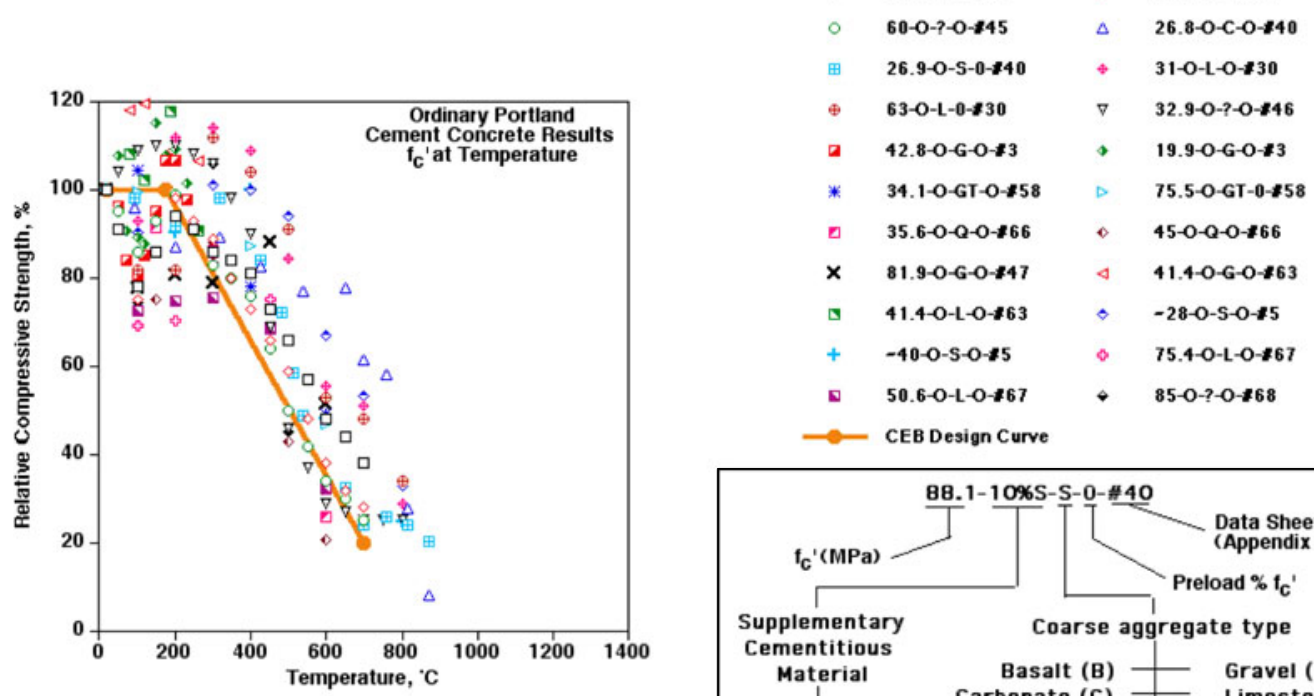

Figure 5. Compilation of data on relative compressive strength vs temperature - OPC concretes. Source: D.J. Naus, "A Compilation of Elevated Temperature Concrete Material Property Data and Information for Use in Assessments of Nuclear Power Plant Reinforced Concrete Structures," NUREG/CR-7031, USNRC, Washington, D.C., December 2010.

materials. Also presented in the report is a general description of heavyweight concrete materials utilized for radiation shielding and the effect of elevated temperature on properties and shielding effectiveness of several shielding concretes is identified. Design codes and standards that address concrete under elevated temperature conditions are listed. Examples of methods that can be utilized for assessment of concrete exposed to high temperatures are noted. Temperature-dependent properties of mild steel and prestressing materials for use with Portland cement concretes are provided. Finally, examples of constitutive relationships for many of the mechanical and physical properties addressed are presented. The emphasis of the report was on presentation of data related to the effect of elevated temperature on the mechanical and physical properties of concrete.

Mechanical property-related items addressed include: stress and strain characteristics, Poisson's ratio, modulus of elasticity, compressive strength, thermal cycling, tensile strength, shrinkage and creep, concrete-steel reinforcement bond strength, fracture energy and fracture toughness, long-term exposure, radiation shielding effectiveness, and multiaxial conditions. Figures 5 and 6 present examples of the effect of elevated temperature on the relative (tested at temperature) and residual (permitted to cool to room temperature prior to testing) compressive strengths, respectively, of unsealed ordinary Portland cement concrete test specimens. Test results presented in the report are identified according to the legend provided in each figure. Whenever possible, results in the report are subdivided and presented in terms of normal or high compressive strength concrete [i.e., normal $\left(\mathrm{f}_{c}^{\prime}<60 \mathrm{MPa}\right)$ or high strength $\left.\left(f_{c}^{\prime} \geq 60 \mathrm{MPa}\right)\right]$, type aggregate, and presence and type of supplementary cementitious material. Lightweight and thermally stable concretes and fibrous concretes are also addressed, as well as the effect of being sealed or unsealed during heating, and the impact of sudden cooling.

Thermal effects on physical properties addressed include: porosity and density, coefficient of thermal expansion, thermal conductivity, thermal diffusivity, specific heat, heat of ablation and erosion rates, moisture diffusion and pore pressure, and simulated hot spots. 
EPJ Web of Conferences
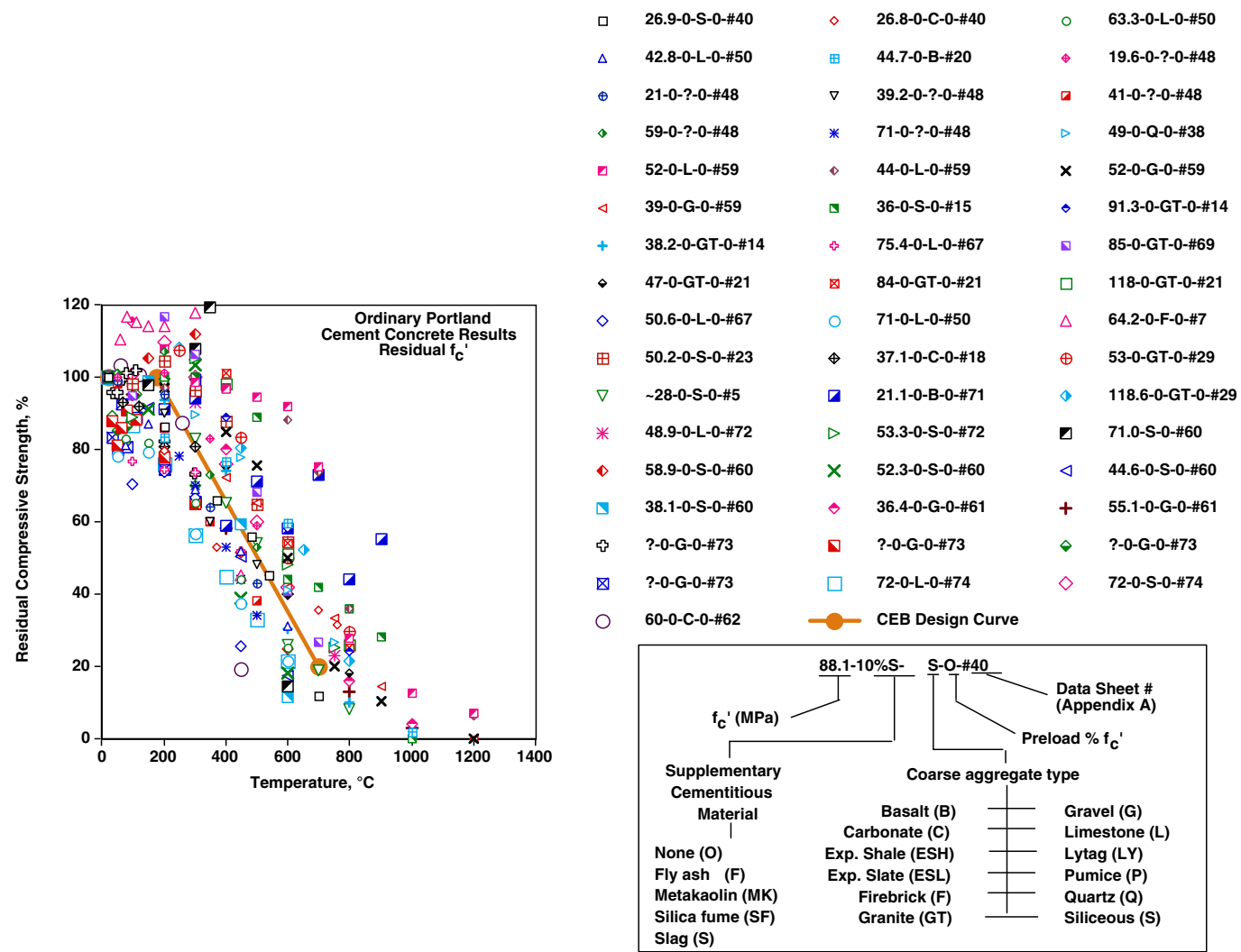

\begin{tabular}{|c|c|c|c|}
\hline $\mathrm{f}_{\mathrm{c}}{ }^{\prime}(\mathrm{MPa})$ & $88.1-10 \% \mathrm{~S}-$ & & $\begin{array}{l}\text { Data Sheet \# } \\
\text { (Appendix A) }\end{array}$ \\
\hline Supplementary & \multicolumn{3}{|c|}{ Coarse aggregate type } \\
\hline $\begin{array}{c}\text { Cementitious } \\
\text { Material }\end{array}$ & Basalt (B) & & Gravel (G) \\
\hline & Carbonate (C) & & Limestone (L) \\
\hline None (0) & Exp. Shale (ESH) & - & Lytag (LY) \\
\hline Fly ash (F) & Exp. Slate (ESL) & & Pumice (P) \\
\hline Metakaolin (MK) & Firebrick (F) & & Quartz (Q) \\
\hline Silica fume (SF) & Granite (GT) & & Siliceous (S) \\
\hline
\end{tabular}

Figure 6. Compilation of data on residual compressive strength vs temperature - OPC concretes. Source: D.J. Naus, "A Compilation of Elevated Temperature Concrete Material Property Data and Information for Use in Assessments of Nuclear Power Plant Reinforced Concrete Structures," NUREG/CR-7031, USNRC, Washington, D.C., December 2010.

\section{SUMMARY}

As concrete ages, changes in its properties will occur as a result of continuing microstructural changes (i.e., slow hydration, crystallization of amorphous constituents, and reactions between cement paste and aggregates), as well as environmental influences. These changes do not have to be detrimental to the point that concrete will not be able to meet its performance requirements. Concrete, however, can suffer undesirable changes with time because of improper specifications, a violation of specifications, or adverse performance of its cement paste matrix or aggregate constituents under either physical or chemical attack. In general, NPP concrete structure's performance has been very good with the majority of identified problems initiating during construction and corrected at that time; however, aging of concrete structures occurs with the passage of time that can potentially result in degradation if its effects are not controlled.

Periodic inspection, maintenance, and repair are key elements in managing the aging of concrete structures. Safety-related NPP concrete structures are described and commentary on continued service assessments of these structures is provided. In-service inspection and testing requirements in the U.S. are summarized. The license renewal process in the U.S. is outlined and its current status noted. A summary of operating experience related to U.S. NPP concrete structures is provided. 
AMP 2010

Several candidate areas are identified where additional research would be of benefit to aging management of NPP concrete structures: (1) compilation of material property data for long-term performance and trending, evaluation of environmental effects, and assessment and validation of nondestructive evaluation methods; (2) evaluation of long-term effects of elevated temperature and radiation on concrete behavior; (3) improved damage models and acceptance criteria for use in assessments of the current as well as estimating the future condition of the structures: (4) improved constitutive models and analytical methods for use in determining nonlinear structural response (e.g., accident conditions); (5) non-intrusive methods for inspection of thick-walled, heavily-reinforced concrete structures and basemats; (6) global inspection methods for metallic pressure boundary components (i.e., steel containments and liners of concrete containments) including inaccessible areas and backside of liner; (7) data on application and performance (e.g., durability) of repair materials and techniques; (8) utilization of structural reliability theory incorporating uncertainties to address time-dependent changes to structures to assure minimum accepted performance requirements are exceeded and to estimate on-going component degradation to estimate end-of-life; and (9) application of probabilistic modeling of component performance to provide risk-based criteria to evaluate how aging affects structural capacity. Finally an update on current ORNL activities related to aging-management of concrete structures is provided: development of operating experience database, application of structural reliability theory, and compilation of elevated temperature concrete material property data and information.

\section{References}

[1] Building Code Requirements for Structural Concrete and Commentary, ACI Standard 318-05, American Concrete Institute, Farmington Hills, Michigan (November 2005).

[2] Assessment and Management of Major Nuclear Power Plant Components Important to Safety: Concrete Containment Buildings, IAEA-TECDOC-1025, International Atomic Energy Agency, Vienna, Austria (June 1998).

[3] S. Smith and F. Gregor, BWR Containments License Renewal Industry Report; Revision 1, EPRI TR-103840, Electric Power Research Institute, Palo Alto, California (July 1994).

[4] D. Deng, J. Renfro, and J. Statton, PWR Containments License Renewal Industry Report; Revision 1, EPRI TR-103835, Electric Power Research Institute, Palo Alto, California (July 1994).

[5] ASME, Rules for Construction of Nuclear Power Plant Components, ASME Boiler and Pressure Vessel Code, Sect. III, New York, New York (2007).

[6] D.J. Naus, C.B. Oland, and B.R. Ellingwood, Final Report Inspection of Aged/Degraded Containments Program, ORNL/TM-2005/170, Oak Ridge National Laboratory, Oak Ridge, Tennessee (August 2005).

[7] D.J. Naus, C.B. Oland, and B.R. Ellingwood, "Report on Aging of Nuclear Power Plant Reinforced Concrete Structures," NUREG/CR-6424, U.S. Nuclear Regulatory Commission, Washington, D.C. (March 1996).

[8] D.J. Naus, Primer on Durability of Nuclear Power Plant Reinforced Concrete Structures A Review of Pertinent Factors, NUREG/CR-6927 (ORBL/TM-2006/529), Oak Ridge National Laboratory, Oak Ridge, Tennessee (February 2007).

[9] ACI, Guide for Making a Condition Survey of Concrete In Service, ACI 201.1R-92, American Concrete Institute, Farmington Hills, Michigan (1992).

[10] ACI, Evaluation of Existing Nuclear Safety Related Concrete Structures, ACI 349.3R-02, American Concrete Institute, Farmington Hills, Michigan (2002).

[11] W.C. Liu, P.T. Kuo, and S.S. Lee, Aging Management of Nuclear Power Plant Containments for License Renewal, NUREG-1611, Division of Reactor Program Management, U.S. Nuclear Regulatory Commission, Washington, D.C. (September 1997). 
EPJ Web of Conferences

[12] USNRC, Maintenance Rule, Inspection Procedure 62706, U.S. Nuclear Regulatory Commission, Washington, D.C. (December 13, 2000).

[13] USNRC, Inspection of Structures, Passive Components, and Civil Engineering Features at Nuclear Power Plants, Inspection Procedure 62002, U.S. Nuclear Regulatory Commission, Washington, D.C. (December 31, 1996).

[14] USNRC, Inspection of Steel and Concrete Containment Structures, Inspection Procedure 62003, U.S. Nuclear Regulatory Commission, Washington, D.C. (June 11, 1997).

[15] License Renewal Inspection, Inspection Procedure 71002, U.S. Nuclear Regulatory Commission, Washington, D.C. (February 2, 2005).

[16] USNRC, Inservice Inspection, Inspection Procedure 73753, U.S. Nuclear Regulatory Commission, Washington, D.C. (June 24, 1998).

[17] NEI, Industry Guidelines for Monitoring the Condition of Structures at Nuclear Power Plants, NEI 96-03, Nuclear Energy Institute, Washington, D.C. (July 1996).

[18] F.E. Gregor and J.J. Carey, "COSTAR - Concrete Structures Aging Reference Manual - A Structures Condition Assessment Tool," Paper 1310, in Transactions of the 16th International Conference on Structural Mechanics in Reactor Technology, Washington, D.C. (August 2001).

[19] ASCE, Guidelines for Structural Condition Assessment of Existing Buildings, SEI/ASCE 11-99, American Society of Civil Engineers, Reston, Virginia (2000).

[20] ASME, "Section XI, Rules for Inservice Inspection of Nuclear Power Plant Components," ASME Boiler and Pressure Vessel Code, American Society of Mechanical Engineers, New York (2007).

[21] Concrete Society, Diagnosis of Deterioration in Concrete Structures - Identification of Defects, Evaluation, and Development of Remedial Action, Technical Report No. 54, Concrete Society, Berkshire, United Kingdom (2000).

[22] RILEM Committee 104-DDC, "Draft Recommendations for Damage Classification of Concrete Structures," Materials and Structures 27, pp. 362-369 (1994).

[23] Office of Federal Regulations, "Appendix J - Primary Reactor Containment Leakage Testing for Water-Cooled Reactors," pp. 748-753 in Code of Federal Regulations, 10 CFR Part 50, Office of Federal Register, Washington, D.C. (1995).

[24] ASME, ASME Boiler and Pressure Vessel Code, American Society of Mechanical Engineers, New York (2007).

[25] USNRC, "Primary Reactor Containment Leakage Testing for Water-Cooled Power Reactors," Federal Register, Vol. 60, No. 186, pp. 49495-49505, U.S. Nuclear Regulatory Commission, Washington, D.C. (1995).

[26] USNRC, Lessons Learned from Regional Inspections of Licensee Actions in Response to IE Bulletin 80-11, Inspection Notification 87-67, U.S. Nuclear Regulatory Commission, Washington, D.C. (1987).

[27] USNRC, Masonry Wall Design, Inspection Enforcement Bulletin 80-11, U.S. Nuclear Regulatory Commission, Washington, D.C. (1980).

[28] USNRC, Inspection of Water-Control Structures Associated with Nuclear Power Plants, Regulatory Guide 1.127, Rev. 1, U.S. Nuclear Regulatory Commission, Washington, D.C. (1978).

[29] USNRC, 2009-2010 Information Digest, NUREG-1350, Vol. 21, U.S. Nuclear Regulatory Commission, Washington, D.C. (August 2009).

[30] USNRC, Generic Aging Lessons Learned (GALL) Report, NUREG-1801, Vol. 2, Rev. 1, Division of Regulatory Improvement Programs, U.S. Nuclear Regulatory Commission, Washington, D.C. (September 2005).

[31] USNRC, Standard Review Plan for Review of License Renewal Applications for Nuclear Power Plants, NUREG-1800, Rev. 1, Division of Regulatory Improvement Programs, U.S. Nuclear Regulatory Commission, Washington, D.C. (September 1995).

[32] ACI, Guide to Durable Concrete, ACI 201.2R-01, ACI Committee 201, American Concrete Institute, Farmington Hills, Michigan (2001). 
AMP 2010

[33] ACI, Specifications for Structural Concrete, ACI Standard 301-05, ACI Committee 301, American Concrete Institute, Farmington Hills, Michigan (2005).

[34] ACI, Code Requirements for Nuclear Safety Related Concrete Structures and Commentary, ACI 349-01, American Concrete Institute, Farmington Hills, Michigan (June 2001).

[35] USNRC, "Standard Format and Content for Applications to Renew Nuclear Power Plant Operating Licenses," Regulatory Guide 1.188, U.S. Nuclear Regulatory Commission, Washington, D.C. (July 2001).

[36] NEI, "Industry Guideline for Implementing the Reqorements of 10 CFR Part 54 - The License Renewal Rule," NEI 95-10 (Rev. 6), Nuclear Energy Institute, Washington, D.C. (June 2005).

[37] D.J. Naus, Concrete Component Aging and Its Significance Relative to Life Extension of Nuclear Power Plants, NUREG/CR-4652, U.S. Nuclear Regulatory Commission, Washington, D.C. (September 1986).

[38] P. D. Krauss, Repair Materials and Techniques for Concrete Structures in Nuclear Power Plants, ORNL/NRC/LTR-93/28, Martin Marietta Energy Systems, Inc., Oak Ridge National Laboratory, Oak Ridge, Tennessee (March 1994).

[39] H. Ashar and G. Bagchi, Assessment of Inservice Conditions of Safety-Related Nuclear Plant Structures, NUREG-1522, U.S. Nuclear Regulatory Commission, Washington, D.C. (July 1995).

[40] H. Ashar, D. J. Naus, and C. P. Tan, "Prestressed concrete in U.S. nuclear power plants (Part1)," pp. 30-34 in Concrete International, 16(5), American Concrete Institute, Farmington Hills, Michigan (May 1994).

[41] H. Ashar, C. P. Tan, and D. J. Naus, "Prestressed concrete in U.S. nuclear power plants (Part 2)," pp. 58-61 in Concrete International, 16(6), American Concrete Institute, Farmington Hills, Michigan (June 1994).

[42] H. Ashar and D. Jeng, "Effectiveness of in-service inspection requirements of prestressed concrete containments - U.S. experience," Proceedings of Second International Conference on Containment Design and Operation held 14-17 October in Toronto, Ontario, Canada (1990).

[43] J.I. Braverman, C.H. Hofmayer, R.J. Morante, S. Shteyngart, and P. Bezler, "Assessment of AgeRelated Degradation of Structures and Passive Components for U.S. Nuclear Power Plants," NUREG/CR-6679, U. S. Nuclear Regulatory Commission, Washington, D.C. (August 2000).

[44] USNRC, Degradation of Prestressing Tendon Systems in Prestressed Concrete Containments, NRC Information Notice 99-10, Rev. 1, U.S. Nuclear Regulatory Commission, Washington, D.C. (1999).

[45] http://www.ne.doe.gov/np2010/neNP2010NRCworkshop02192008.html

[46] http://www.ne.doe.gov/pdfFiles/LifeAfter60WorkshopReport.pdf

[47] D.J. Naus, "Concrete Materials and Structures - Aging and Life Beyond 60 Years," Proceedings of Life Beyond 60 Workshop Summary Report, NRC/DOE Workshop U.S. Nuclear Power Plant Life Extension Research and Development, Bethesda, Maryland (February 19-21, 2008).

[48] C. Hofmayer, "Concrete Structures," Proceedings of Life Beyond 60 Workshop Summary Report, NRC/DOE Workshop U.S. Nuclear Power Plant Life Extension Research and Development, Bethesda, Maryland (February 19-21, 2008).

[49] https://inlportal.inl.gov/portal/server.pt/community/lwr_sustainability_ program/442/introduction

[50] C.B. Oland and D.J. Naus, Summary of Materials Contained in the Structural Materials Information Center, ORNL/NRC/LTR-94/22, Martin Marietta Energy Systems, Inc., Oak Ridge National Laboratory, Oak Ridge, Tennessee (November 1994).

[51] W. Ren, "Gen IV Materials Handbook GIF release for Architecture and Functionality Demonstration - Introduction and Navigation Guide,” ORNL/GEN4/LTR-08-002_R3, Oak Ridge National Laboratory, Oak Ridge, Tennessee (April 22, 2009). 
[52] M.F. Marchbanks, R.A. Moen, and J.E. Irvin, "The Nuclear Systems Materials Handbook," HEDL-SA-871, Hanford Engineering development Laboratory, Richland, Washington (January 1, 1976).

[53] J.I. Braverman, C.A. Miller, B.R. Ellingwood, D.J. Naus, C.H. Hofmayer, S. Shteyngart, and P. Bezler, "Probability-Based Evaluation of Degraded Reinforced Concrete Components in Nuclear Power Plants," NUREG/CR-6715, U.S. Nuclear Regulatory Commission, Washington, D.C. (2001).

[54] D.J. Naus, C.B. Oland, B. Ellingwood, C.J. Hookham, and H.L. Graves, "Summary and Conclusions of a Program to Address Aging of Nuclear Power Plant Concrete Structures." Nuclear Engrg. and Des. 194(1):73-96 (November 1999).

[55] D.J. Naus, B. R. Ellingwood, and H. L. Graves, "Methods for Assessing NPP Containment Pressure Boundary Integrity," Nuclear Engrg. \& Des. 228(1-3): 55-72 (2004).

[56] D.G. Elms, "Risk Assessment," in Engineering Safety (D. Blockley, Editor), McGraw-Hill International, Berkshire, United Kingdom, pp. 28-46 (1992).

[57] B.R. Ellingwood, "Acceptable Risk Bases for Design of Structures," Progress in Structural Engineering and Materials 3(2), pp. 170-179 (2001).

[58] B.R. Ellingwood, "Strategies for Mitigating Risk to Buildings From Abnormal Load Events," Int. J. of Risk Assessment and Mgt. 7(6/7):828-845 (2007).

[59] Y.K. Wen and B. R. Ellingwood, "The Role of Fragility Assessment in Consequence-Based Engineering," Earthquake Spectra, EERI 21(3), pp. 861-877 (2005).

[60] DOE, Natural Phenomena Hazards Design and Evaluation Criteria for Department of Energy Facilities, DOE STD 1020-2002, U.S. Department of Energy, Washington, D.C. (2002).

[61] ASCE, Seismic Design Criteria for Structures, Systems and Components in Nuclear Facilities, ASCE/SEI Standard 43-05, American Society of Civil Engineers, Reston, VA (2005).

[62] Y. Mori, Y. and B.R. Ellingwood, "Reliability-Based Service Life Assessment of Aging Concrete Structures.” J. Struct. Engrg. ASCE 119(5):1600-1621 (1993).

[63] B.R. Ellingwood and D.J. Naus, "Chapter 6, Aging Nuclear Structures," in Modeling Complex Engineering Structures, Ed. by R. E. Melchers and R. Hough, pp. 137-170, American Society of Civil Engineers, Reston, Virginia (2007).

[64] P. Anderson, M. Hansson, and S. Thelandersson, "Reliability-Based Evaluation of the Prestress Level in Concrete Containments with Unbonded Tendons," Structural Safety 30(1), pp. 78-89 (2008).

[65] M.H. Faber, "Reliability Assessment of Existing Structures.” Progress in Struct. Engrg. and Mat. 2(2):247-253 (2000).

[66] M. Ciampoli, M. and B.R. Ellingwood, "Probabilistic Methods for Assessing Current and Future Performance of Concrete Structures in Nuclear Power Plants," Materials and Structures, RILEM 35:3-14 (2002).

[67] A. Petcherdchoo, L. Neves, and D.M. Frangopol, "Optimizing Lifetime Condition and Reliability of Deteriorating Structures with Emphasis on Bridges.” J. Struct. Engrg. ASCE 134(4):544-552 (2008).

[68] J.I. Braverman, C.A. Miller, C.H. Hofmayer, B.R. Ellingwood, D.J. Naus and T.Y. Chang, "Degradation Assessment of Structures and Passive Components at Nuclear Power Plants," International Journal of Nuclear Engineering and Design 228(1-3), pp. 283-304 (2004).

[69] R.P. Kennedy and M. Ravindra, "Seismic Fragilities for Nuclear Power Plant Risk Studies," International Journal of Nuclear Engineering and Design 79(1), pp. 47-68 (1984).

[70] G.A. Khoury, "Effect of Fire on Concrete and Concrete Structures," Progress in Structural Engineering Materials 2, pp. 429-447 (2000).

[71] I.A. Fletcher, S. Welch, J.L. Torero, R.O. Carvel, and A. Usmani, "Behaviour of Concrete Structures in Fire," Thermal Science 11(2), pp. 37-52 (2007). 
[72] K. Willam and I. Rhee, "Thermal Degradation Effects in Concrete Material Systems," NSF-FHWA Workshop on Imaging and Simulation of Concrete Structures, Northwestern University, Evanston, Illinois, July 30-31 (2003).

[73] "Code for Concrete Reactor Vessels and Containments," Nuclear Power Plant Components, ASME Boiler and Pressure Vessel Code, Section III, Division 2, American Society of Mechanical Engineers, New York (July 2007).

[74] D.J. Naus, "A Compilation of Elevated Temperature Concrete Material Property Data and Information for Use in Assessments of Nuclear Power Plant Reinforced Concrete Structures," NUREG/CR-7031, USNRC, Washington, D.C. (December 2010). 